\title{
Improving Students' Mathematical Understanding and Proving Ability by Using Moore Method
}

\author{
Rizky Oktaviana Eko Putri \\ ${ }^{1}$ Universitas Islam Majapahit, Jalan Raya Jabon KM 0,7 Mojokerto \\ rizky_putri@unim.ac.id
}

\begin{abstract}
Abstrak (Times New Roman 11, spasi 1, spacing before 12 pt, after 2 pt)
Kemampuan pembuktian matematika merupakan salah satu kemampuan yang dibutuhkan oleh siswa untuk menunjang pembelajaran matematika di tingkat yang lebi tinggi. Namun, beberapa penelitian menemukan bahwa kemampuan pembuktian tersebut sulit untuk dikuasai oleh siswa. Ada banyak metode yang dapat digunakan oleh guru untuk membantu siswa dalam meningkatkan kemampuan siswa dalam membuktikan. Salah satu metode yang dapat dipakai yaitu Metode Moore. Studi literatur ini menggunakan analisis metode dari hasil penelitian yang relevan. Tujuan dari studi ini adalah menyediakan informasi tentang keefektifan metode Moore dalam meningkatkan pemahaman matematika dan kemampuan pembuktian siswa. Hasil studi menyediakan informasi bagi guru tentang bagaimana menerapkan metode Moore secara efektif.
\end{abstract}

Kata Kunci: Metode Moore, Pemahaman Matematika, Kemampuan Pembuktian Matematika

\begin{abstract}
Mathematical proving ability is one of ability that is needed by students to support their mathematical study in higher levels. Unfortunately, some studies found that this ability is barely hard for students to master. There are so many methods that can be used by teachers in order to help students improving their ability. One of learning method that can improve students' proving ability is Moore Method. This literature study used analysing and summarizing method from the results of relevant research that has been done. The aim of this study was provide information about the effectiveness of Moore Method in improving students' mathematical understanding and proving ability. Results provide informations for teachers about how to apply Moore Method effectively.
\end{abstract}

Keywords: Moore Method, Mathematical Understanding, Mathematical Proving Ability

\section{Introduction}

Mathematical proving ability is one of the essential ability that should be posses by all mathematics students. This ability is needed by students to support their mathematical study in higher levels, because the truth of each proposed mathematical statement must be tested before the statement was used as a basic or reference for testing other mathematical statement (Solow, 1990). However, some studies find that mathematical proving ability still become a big problem for high school students and undergraduate students. According to Moore, most of students' difficulties on proving caused of their lack of understanding on mathematical concepts and definitions so that they were unable to construct a mathematical 
proof and to write mathematical notation or to use mathematical language correctly (Maya, 2011).

Students often say that they can follow and understand the proving steps of mathematical problem that explained by their teacher, but they unable to compose proofs by themselves when required to do so for homework (Barnard, 2000). Furthermore, Moore (Weber, 2003) proposed that sometimes students could state definition of a concept, but they did not understand meaningfully. That disadvantages caused students posed difficulty when they were asked to explain the concept by their own words or to generate an example from a previous concept. Weber (2003), stated that in general students knew what had to do in composing a proof, they could reason deductively, restate and manipulate definition and draw a valid conclusion. However, to know logical rules and definition did not guarantee that students could reason the concept meaningfully. Maya (2011) stated that there was quite strong association between mathematical understanding ability and mathematical proving ability. In other words, Students need to be able to comprehend how ideas build upon and connect with other ideas. In mathematics, a student may understand new material when he or she can make connections with his or her existing mathematical knowledge (LeMire, 2012).

Teachers should be able to deliver knowledge to students meaningfully, it means students not only receive knowledge that given by their teacher but also students must understand about the reason why they learn. Some teachers or lectures usually use conventional learning to teach students about mathematical proving problem. Conventional learning method tends to create passive students because students just watching and listening their teacher's explanation (Maya,2011). Moore (Weber, 2003) was sure that students would get a few knowledge of advanced mathematics if they only copied lecturer's proof passively. On the other hand students would learn more mathematics concepts and its proof if they tried to compose a mathematical statement by themselves. The Moore method assumes that student has natural inquisitiveness, he must be active in learning and as consequent self-confidence and self-directedness is established and builds within the individual (McLoughlin, 2008). Moore method found by Prof. R.L. Moore, with his quick mind and restless spirit he found the lecture method rather boring - in fact, mind dulling, based on his experience he created a new method that makes students become the main player in a learning activity usually called by student centered (Jones, 2012).

According to Moore's findings about students' difficulties on proving, most of them were caused by their lack of understanding on mathematical concepts and definitions so that they were unable to construct a mathematical proof and to write mathematical notation or to use mathematical language correctly. Therefore, before students able to construct a proof, they should have to master all relevant definitions and theorems. In fact, it is obvious that students' mathematical proving ability associated with their mathematical understanding ability.

\section{Research Method}

This literature study used analysing and summarizing method from the results of relevant research that has been done. The aim of this study was provide information about the effectiveness of Moore Method in improving students' proofing ability. 


\section{Results}

The Moore method assumes that student has natural inquisitiveness, he must be active in learning and as consequent self-confidence and self-directedness is established and builds within the individual (McLoughlin, 2008:6). Jones (2012), was Moore's student, described about Moore Method as follow:

\section{Selecting}

Moore would begin his class by carefully selecting the members of the class. If a student had already studied about the course somewhere else or had read too much, he would exclude him (in some cases, he would run a separated class for such students). The idea was to have a class as homogeneously ignorant as possible. He would usually warn his students not to read but simply to use their own ability because he wanted the competition as fair as possible.

\section{Giving brief explanations}

After selecting the class, he would tell them briefly his view of the axiomatic method and gave some motivating examples to illustrate their meaning.

\section{Giving tasks to prove some theorems}

$\mathrm{He}$ would state some definitions and theorems after giving some axioms and examples. He simply read them from his book then the students copied them down. He would instruct the class to find the proofs of their own and also to construct examples to show that that the hypotheses of the theorems could not be weakened.

\section{Presenting the proofs}

He would call some students to prove Theorem 1 in the next meeting. After he became familiar with the abilities of the class member, he would call on them in reverse order. In this way will give the more unsuccessful students first chance when they did get a proof, though he was not inflexible in this procedure but it was that he preferred it.

Jones (2012) added, when a student stated that he could prove Theorem $\mathrm{x}$, he would ask to present his proof. Then the other students, especially those who had not been able to discover a proof, would make sure that the proof presented was correct and convincing. When a mistake appeared in a proof, everyone would patiently wait for the student who did the proof to solve it. If he could not then he would sit down. Moore would ask next student to try or he thought the difficulty encountered was interesting. He would save that theorem until next meeting and go on to the next unproved theorems.

Professor Moore succeeded change way of teaching from old learning style (teacher centered) became a meaningful learning for his students by using his method. When the Moore Method applied by others, the results often were disappointing. It can be caused by disability of teachers to divide their students based on their ability. Moreover, students usually unfamiliar in proving theorems, they still need help from the teacher. Finally, the Moore method sometimes creates an unhealthy atmosphere of competition and isolation among students (Cohen, 1982).

Recently, some Mathematics teachers modified the Moore Method so that can avoid the disadvantages. Although, this Modified Moore method was developed to teach mathematics, Cohen (1982) stated, Modified Moore method is also based on principles that apply to the teaching of most subjects, such as:

1. Students understand better and remember longer what they discover themselves than is told to them 
2. People master an idea most thoroughly when they teach it to someone else

3. Effective writing and clear thinking inextricably linked

Briefly, the method divides a class into small groups, each of which is responsible for a weekly question. Over the course of a week each small group will study and answer the question, write a short paper presenting the answer, and prepare to teach the question and its answer to the rest of the class. The questions and their answers contain all the ideas covered in the course. These are some important points that need to be considered by teacher:

\section{Preparation and Scheduling for the Course}

The first task for the instructor is to break the course material into a list of questions. These may resemble questions asked on a take-home examination at the end of the course. An average student with some coaching from the instructor should be able to understand a question and write an answer to it in one week. There should be enough questions so that any student who can answer all of them thoroughly will have mastered all the material for the course.

\section{Organizing the Class and Assigning Work}

The first day of class is devoted to a thorough explanation of the method, its objectives, and what is expected of the students. The class is then divided into teams of two or three students each. Teams of three work best. These do not change until midterm when all teams must change for the second half of the term. New teams are assigned to avoid those consisting only of weak or only of strong students. At the end of each class meeting the instructor assigns questions for the next class meeting. Several teams may be assigned the same question. After assigning the questions, the instructor announces the schedule for the first coaching session. In addition, each team must be prepared to explain to the class its question and the answer it has found. All teams are expected to be prepared for each class meeting, although only one team per question will be called upon to make an oral presentation.

\section{The Coaching Sessions}

The first coaching session follows the class meeting by one or two days. Each team is required to come during that part of the first coaching session dealing with its question. If several teams are dealing with the same question, all of those teams come at the same time. Each team is expected to have met once prior to this session to try to understand the basics and the question and to formulate ideas about the answer. When students have discovered the answer before the session, the instructor simply listens to the team's answer and provides whatever help is necessary to make the team's explanation very clear. When a team comes in a state of confusion, on the other hand, the instructor must do some explaining. In the 20 or 30 minutes devoted to each question, he must try to lead the students to the heart of the matter, using a Socratic style as long as time permits it. Sometimes this means asking one or two questions to help students understand how they almost had the idea themselves. At other times it means giving a complete explanation, and hoping that the students will make a discovery on some other questions. I try to make sure that at least one member of each team has a basic understanding before the teams leave. The second coaching session follows the first by three days or more. During those days the students prepare drafts of their papers. The teams meet and discuss the work and a team might even agree on a rough written draft of its paper. Each member must then write his or her own draft without consultation. All teams gather for the second coaching session during which students exchange their drafts with their teammates for peer review. 
The reviewers pay close attention to content, clarity and style, and make suggestions for improvement. While this peer review is taking place, the instructor selects drafts at random and reviews them in front of the team. This provides at least one team member with professional comment on a draft, and at the same time gives each member a chance to watch how the instructor reviews. I reserve some time to speak to the class as a whole about common errors or misconceptions found during my reviews

4. The Weekly Papers

Each paper must consist of a clear, concise, cogent answer to the team's question for the week, written in a style appropriate to the subject for the course, and with careful attention to syntax, punctuation and correct usage of notation commonly used by professionals in the subject. Each team decides how the paper is to be written. Sometimes the students divide a paper into sections with each member responsible for writing a section. Sometimes a single student writes the entire paper; however, that student may not write another one until the other members of the team have also written an entire paper.

5. The Class Meetings

At the beginning of the class meeting each team passes a copy of its paper out to all students. Two copies go to the instructor, one to be corrected and returned. The team called upon for the first question for the week then makes its presentation. Each team must plan its presentation and allow time for questions from the class. Usually each member is responsible for one part of the presentation. The instructor's role during the presentation is a delicate matter. If there is a point that seems unclear, teacher should wait for a student to ask about it; but if no one does, then teacher should ask. Teacher willing to help a team clarify an explanation, but only after teacher sense that no one else can do it. With this method students are much less willing to let the instructor dominate discussion than in more conventional classes. They have invested much time and energy in their preparation, and are anxious to explain their ideas clearly to their classmates

Based on findings of a research by Maya (2011), it was obtained some conclusion that there were no differences on mathematical understanding and proving abilities of students taught by modified Moore learning method and taught by conventional teaching either entirely or in each level of students' prior mathematics ability. Those abilities were classified as fairly good, however according to number of students who obtained medium and high scores on mathematical understanding ability, in modified Moore learning method there more students than number of students with medium and high mathematical understanding ability of conventional teaching. Those conditions pointed out that modified Moore learning method was a little more effective compared to conventional teaching on improving mathematical understanding and proving abilities.

Moreover, during modified learning method students performed active learning independently, were unafraid to pose question and to present and to explain their ideas in front of class, while students on conventional class were more passive in solving problems and tended to wait lecturer's explanation. Although there were no differences of students' mathematical and proving abilities, but according to learning process, the modified Moore learning method gave more chances for students to learn actively. Those illustrations supported that modified learning method was better than conventional teaching in improving mathematical understanding and proving abilities and habits of good learning. The last phrase was very importance for learning further advanced mathematics courses.

Moore (Maya, 2011) proposed in detailed seven difficulties on mathematical proving namely:

1. Students were unable to generate an example

2. Students were unable to explain a concept into simpler form of concepts 
3. Students did not understand standard mathematical notation and mathematical language.

4. Students did not know to start a proof.

5. Students' concept understanding did not satisfy for starting a proof.

6. Students' lack of understanding toward mathematical notation caused they used inexact or confusing mathematical language

Students were unable to seek relation among concepts, definition, theorems, and among theorem and relevant definition.

\section{Conclusion}

The Moore method is a learning method found by R.L. Moore that has main goal to improve students' mathematical understanding and proving ability. This method does not give a good result when other lecturers applied it in their class. That is why some educators modified the Moore method so that it can give significant advantages for students. The method effectively raises the level of communication between students. Since all students are responsible for all questions on examinations, the presenting teams try hard to teach and the other students demand the clarity they need in order to learn.

Since students write every week and receive prompt evaluation of their writing, they make substantial improvement. They also learn to appreciate the connection between understanding a subject and writing about it.

Furthermore, most students respond well to the responsibility placed on them by the Modified Moore method. They are willing to work hard for a teacher who pays attention to their thinking and writing. Most students are stimulated by the change from passive to active learning.

Those illustrations supported that modified learning method was better than conventional teaching in improving mathematical understanding and proving abilities and habits of good learning.

\section{References}

Barnard, T. 2000. Why Are Proofs Difficult?. In The Mathematical Gazette [Online], Vol. 84, No. 501, November, (2000), 415-422. Available at: http://www.jstor.org/

Cohen, W. David. 1982. A Modified Moore Method for Teaching Undergraduate Mathematics. Available at: www.maa.org/pubs/monthly.html [August - September 1982]

Jones, F. Burton. 2012. The Moore Method. [Online] Available at: http://celebratio.org/

LeMire, Steven D. 2012. The Devalued Student: Misalignment of Current Mathematics Knowledge and Level of Instruction [Online], The Mathematics Educator 2012 Vol. 22, No. 1, 63-83. Available at: http://math.coe.uga.edu/tme/tmeonline.html

McLoughlin, M. Padraig M.M. 2008. Inquiry Based Learning: A Modified Moore Method Approach to Encourage Student Research. Texas: Legacy of R.L. Moore Conference

Solow, D. 1990. How to Read and Do Proofs: An Introduction to Mathematical Thought Processes. Kanada: John Wiley \& Sons, Inc. 
Weber, K. 2001. Student Difficulty in Constructing Proofs: The Need for Strategic Knowledge. In Educational Studies in Mathematics [Online], Volume 48: 101-119. Available at: http://www.jstor.org/ 